\title{
浸食性河岸を有する水路を用いた 中規模河床波の形成実験 \\ HYDRAULIC EXPERIMENTS ON FORMATION OF BARS USING ERODIBLE BANK CHANNEL
}

\begin{abstract}
渡邊康玄 $^{1} \cdot$ 島絵梨子 $^{2} \cdot$ 山口里実 ${ }^{3}$
Yasuharu WATANABE, Eriko SHIMA and Satomi YAMAGUCHI

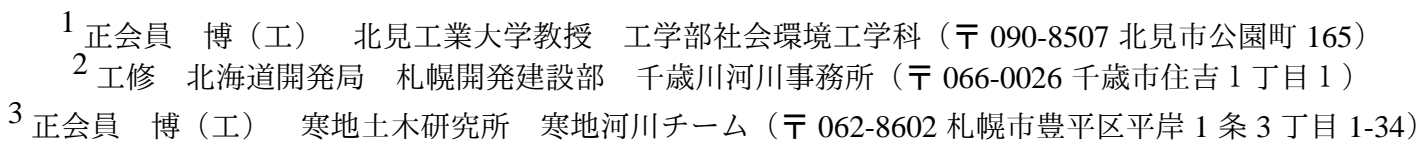

It is an indispensable subject to understand the formation mechanism of the plane shape of a river channel, when considering maintenance of a river channel, and it serves as the basic point of river improvement or river environment. A meandering channel and a braided stream are generally mentioned as the plane shape of a river channel. Research on these formation mechanisms has been conducted. However, the relationship between sand bars and bank erosion which governs the plane shape of a river channel has not been amply clarified. The hydraulic experiments on bar formation using an erodible bank channel were conducted in this research. When alternate bars were formed, straight channel shifted to the meandering channel. When double row bars were formed, there were a case of shifting to meandering channel and a case of shifting to a gourd type channel. When riverbank erosion starts, migration speed of bars becomes slow and the bars develop to the transverse direction. It was confirmed that the observed wavelength of meandering or a gourd type wavelength is almost double of the stability analysis result.
\end{abstract}

Key Words: Bar formation, erodible bank, gourd shaped channel, meandering channel

\section{1.はじめに}

局地的集中豪雨による災害は各地に甚大な災害をも たらしており，今後の防災・減災対策のあり方につい て議論が行われてきている. 中規模河床波の特性や蛇 行河道における河床形状特性は, 流れの偏倚や局所洗 掘を引き起こすことから, 従来より数多くの研究が行 われてきており，これまでの河道計画や防災対策に有 益な情報を提供してきている. しかしながら, 従来の 研究では, 水路側壁が固定された基での現象を扱って おり，災害に直接結びつく河岸浸食が生じる場での中 規模河床波の発達や中規模河床波と河岸浸食との関係 については十分に議論されてきていない.

木下 ${ }^{1)}$ は，直線河道において交互砂州の形成に伴い 河岸浸食が生じ蛇行流路が形成されることを初めて指 摘した。また，藤田ら ${ }^{2)}$ および土木学会水理委員会の 「洪水流の三次元流況と流路形態に関する研究」3)では, 中規模河床波の形成に着目し, 側岸浸食性流路におけ る中規模河床波に関する水理実験結果を整理し，固定 側壁水路におけるものと比較して, 波長や波高がやや 小さくなるもののその基本的な特性は一致するとの知 見を得るとともに, 流路形態 (非砂州直線水路, 砂州 を伴う直線水路, 蛇行水路, 網状流路) を川幅水深比 と水深粒径比で整理されることを示すなど，浸食性河 岸における中規模河床波の形成と流路形態との関係に
着目し, 有益な知見を示している. しかしながら, 理 論的な解明にまではいたっていないものの, 近年河岸 浸食を伴う流路における中規模河床波の形成理論解析 が進められ, 河岸浸食と中規模河床波の形成の関係が 論じられるようになってきている. 島田・清水・長谷 川ら ${ }^{4)}$ は Blondeaux \& Seminara ${ }^{5)}$ の平面不安定理論と の比較から交互砂州の流路変動への影響を論じ, Uddin , Izumi \& Hasegawa6) ${ }^{6}$ は河岸浸食が河岸近傍の剪断力に 比例するとして安定解析を行い, 河岸浸食による中規 模河床波形成への影響を示している. さらに, 渡邊・長 谷川ら 7) は, 流路幅が縦断方向に周期的に変化し, 節 部（流路幅の狭い箇所）と腹部（流路幅の広い箇所）が 交互に現れる節腹連続流路（節腹連続流路）の形成に 関し中規模河床波の安定解析から論じている.

以上のように, 理論解析も進められてきており, 現 象の更なる理解が可能となってきていることから, 本 論文では, 河岸浸食を伴う中規模河床波の形成に関す る水理実験を行い, 近年の研究で得られている理論解 析結果との比較を行うこととした.

\section{2. 水理模型実験}

河岸浸食を伴う場合に中規模河床波の形成がどのよ うに変化するかを把握することを目的として, 単列砂 州と複列砂州が形成される水理条件で水理模型実験を 
表-1 水理実験条件

\begin{tabular}{|c|c|c|c|c|c|c|c|c|}
\hline 実験名 & $\begin{array}{c}\text { 初期流路幅 } \\
\widetilde{B_{0}} \\
(\mathrm{~m})\end{array}$ & $\begin{array}{c}\text { 流量 } \\
\widetilde{Q} \\
\left(\mathrm{~m}^{3} / \mathrm{s}\right) \\
\end{array}$ & $\begin{array}{c}\text { 初期水深 } \\
\widetilde{D_{0}} \\
(\mathrm{~m})\end{array}$ & $\begin{array}{c}\text { 平均粒径 } \\
\widetilde{d}_{s} \\
(\mathrm{~mm})\end{array}$ & $\begin{array}{c}\text { 河床 } \\
\text { 勾配 } \\
i_{b} \\
\end{array}$ & $\begin{array}{c}\text { 無次元 } \\
\text { 掃流力 } \\
\theta_{0} \\
\end{array}$ & $\begin{array}{c}\text { 限界 } \\
\text { 掃流力 } \\
\theta_{c} \\
\end{array}$ & $\begin{array}{c}\text { 通水時間 } \\
\widetilde{T} \\
\text { (min.) }\end{array}$ \\
\hline Case1 & 0.25 & 0.00048 & \multirow{5}{*}{0.007} & \multirow{5}{*}{0.765} & \multirow{5}{*}{$1 / 100$} & \multirow{5}{*}{0.056} & \multirow{5}{*}{0.034} & 90 \\
\hline Case2 & 0.30 & 0.00058 & & & & & & 150 \\
\hline Case3 & 0.45 & 0.00087 & & & & & & 150 \\
\hline Case4 & 0.60 & 0.00116 & & & & & & 150 \\
\hline Case5 & 0.75 & 0.00143 & & & & & & 90 \\
\hline
\end{tabular}

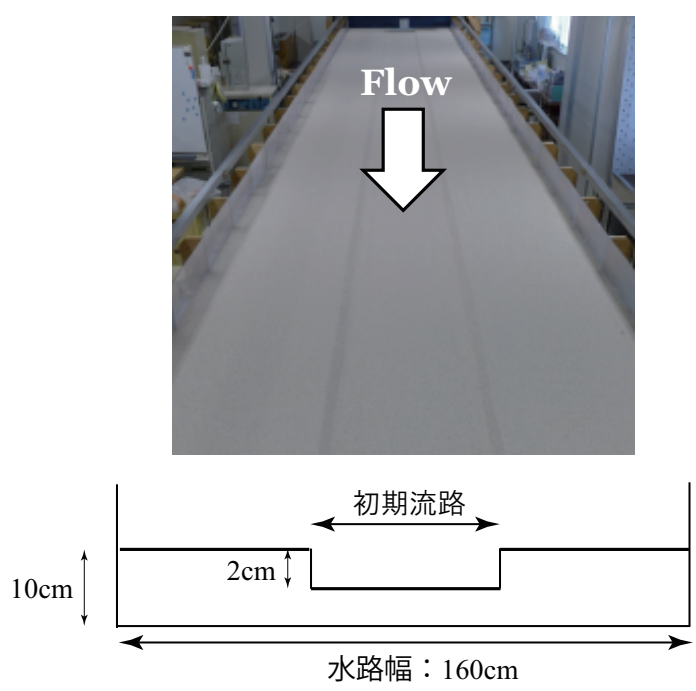

横断図

図-1 実験に用いた水路

行い, 中規模河床波の形状の変化と周期的な河岸浸食 が目視で明確に確認できる段階までの中規模河床波と 河岸浸食の発達過程を把握することとした.

\section{(1) 実験水路}

実験に用いた水路は，幅 $1.6 \mathrm{~m}$ ，長さ $14 \mathrm{~m}$ の可変勾配 直線水路であり, 今回の実験では，水路の勾配を $1 / 100$ に固定している. 図-1 に示すように, 平均粒径 $d_{m}$ が $0.765 \mathrm{~mm}$ の均一な 4 号硅砂を厚さ $10 \mathrm{~cm}$ で水路床に敷 き詰めた後に, 水路中央に深さ $2 \mathrm{~cm}$ の直線河道を人工 的に形成したものを初期流路とした. なお，水路の上下 流端には初期流路と同じ形状の固定堰を設置している.

\section{(2) 実験条件}

実験条件は表-1に示すように, 初期の水深が同じと なるように流量を変化させて, 初期流路幅が異なる 5 ケースの実験を行うこととした。すなわち中規模河床 波の形成パラメータのうち, 川幅水深比のみが異なる 条件としている. 図-2 は, 岸・黒木の中規模河床形態 の領域区分図に今回の実験条件をプロットしたもので ある. Case1 およびCase2 が単列砂州領域, Case4 およ びCase5 が複列砂州領域にそれぞれ属しており, Case3 は単列砂州領域と複列砂州領域の境界に位置する実験 条件となっている. なお, 通水は, 河岸が浸食されて

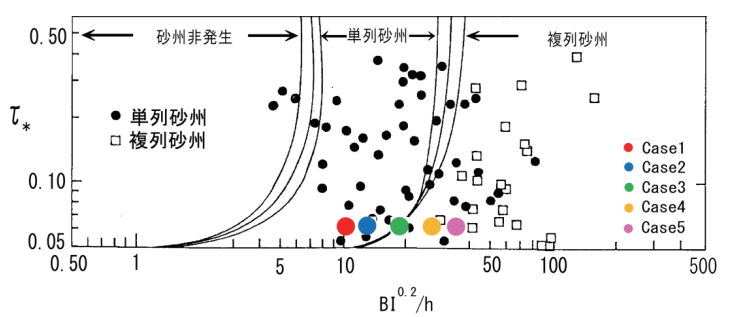

図-2 各ケースの領域区分図における位置

水路側壁に到達する前に停止している.このため, 河 岸浸食を伴う場合の初期の砂州形成機構を把握する実 験となっている．また，上流からは，上流端で河床高 が維持されるように給砂を行っている.

\section{(3) 測定項目}

通水中の河岸浸食状況および砂州形成状況を継続的 に把握する目的で, 上流から $5 \mathrm{~m}$ の位置において水路 真上から 5 分毎に写真撮影を行っている。 また, 通水 終了後には縦横断方向それぞれ $10 \mathrm{~cm}$ および $1 \mathrm{~cm}$ 間隔 でレザー砂面計により詳細な流路形状を把握した。ま た, 通水中には水路下流端において流量を 30 分毎に確 認のため計測している. さらに, 給砂量の把握を目的 として, 10 分間に給砂した量を測定しながら通水して いる.

\section{3. 実験結果}

\section{（1）通水時の中規模河床形態の形成過程と通水後の流路 形状}

Case1 Case5 における，上流端から下流 10m までの 区間の通水停止後の河床形状をコンター図で示したも のが図-3 である.また, Case1 およびCase3について は, 左右岸の初期河岸からの浸食幅の縦断分布を図-4 に示した。

初期流路幅が $25 \mathrm{~cm}$ の Case1 では通水開始から 15 分 程で砂州が形成され，それとほぼ同時に河床波により 流れが河岸に向かう箇所において河岸の浸食が始まっ た。河岸浸食の位置は固定されているもののこの時点 では, 河床波は浸食箇所の固定にかかわらず下流方向 へ移動していった．50 分を経過すると，砂州の縦断方 向への移動はほぼ停止し流路の湾曲が顕著になっていっ た。最終的には，上流からおよそ $3 \mathrm{~m}$ の地点から，図-4 

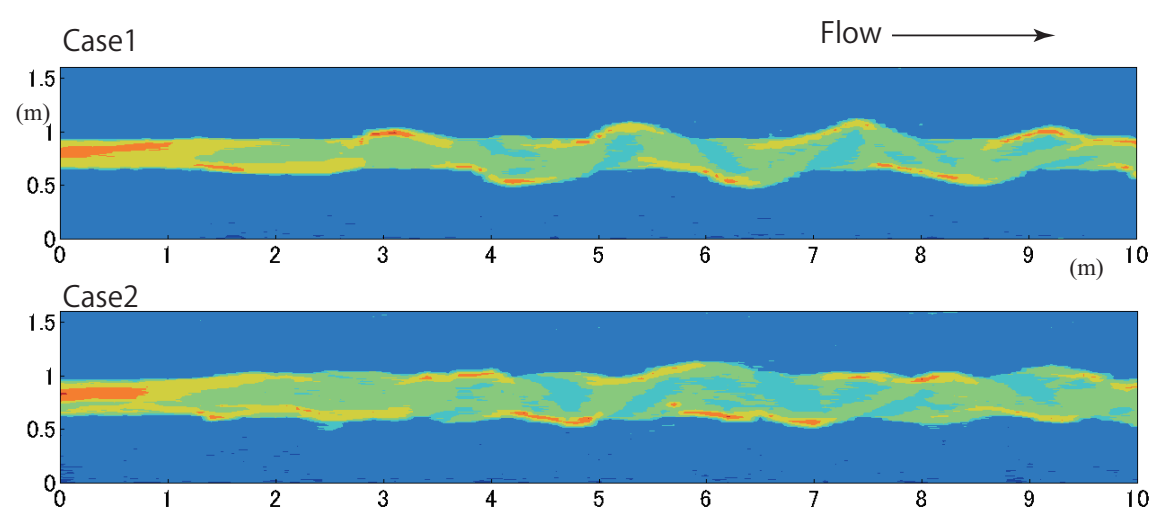

Case3

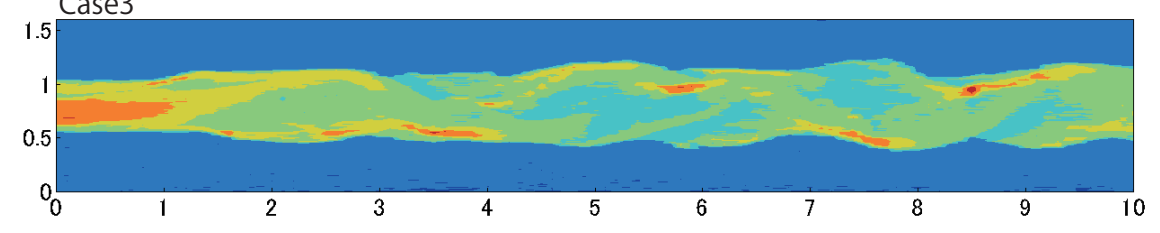

Case4
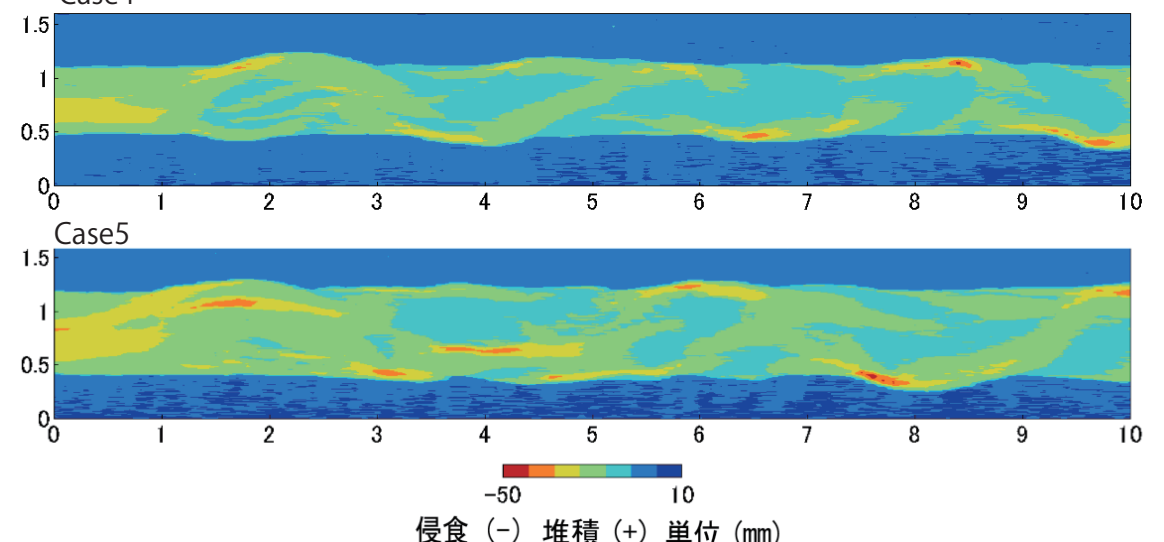

図-3 各ケースの通水終了後の河床コンター図

に示されているように浸食箇所が縦断方向に左右岸交 互に現れる一波長が約 $2 \mathrm{~m}$ の比較的明瞭な蛇行流路が 形成された。

初期流路幅が $30 \mathrm{~cm}$ の Case 2 は, Case 1 と同様に通水 開始から 15 分程で砂州が形成され，通水開始から 20 分程経過したところで河岸の浸食が始まった。河床波 は，浸食位置にかかわらず下流へ移動していることは Case1 と同様であった. しかしながら, 流路の拡幅によ り通水開始 40 分後には河床波が複列状に変化していき, 流路の蛇行形状は不明瞭になった。 その後, 通水開始 から 1 時間 20 分が経過したところで，再度単列化した 砂州の下流への移動とともに, 流路が湾曲状になるよ うに河岸浸食位置が下流へ移動いていく様子が確認さ れた。最終的には，Case1 ほど明瞭ではないが，蛇行流 路が形成された。

初期流路幅 $45 \mathrm{~cm}$ の Case 3 は，通水開始から 10 分程 で複列砂州が形成されすぐに単列化した。その後通水 開始から 30 分経過したところで河岸の浸食が始まると 同時に再度複列砂州が形成された。この時河床波は，局 所的な河岸浸食に関係なく下流へと移動していた。そ の後, 通水開始から 50 分後に河床波の移動が遅くなる とともに複列砂州上の流れが河岸に向かう両岸におい
て顕著な河岸の浸食が始まった。最終的な河道形状は, Case1, Case2 で見られたような蛇行流路は形成されず, 図-4に示されるように浸食箇所が左右岸でほぼ一致し て流路幅が縦断方向に周期的に変化する節腹連続流路 が形成された。

初期流路幅が 60cm の Case4 は, 通水開始から 15 分 程で 3 列砂州が形成され直後に単列ないし複列砂州へ と移行した。また，それとほぼ同時に河岸の浸食が始 まった. 河岸の浸食は, Case1〜Case3 と同様に河床波 の移動とは関係なく, 時間が経過しても初期に浸食し た箇所において進行していった。最終的には，上流か らおよそ $2 \mathrm{~m}$ の地点から一波長が約 $3.5 \mathrm{~m}$ の蛇行形状の 流路が形成された。なお，この蛇行形状は，Case1や Case2 と異なり, 両岸が浸食されている箇所も存在し, 節腹連続流路の要素も含まれている形状となった。

初期流路幅が $75 \mathrm{~cm}$ の Case 5 は，通水開始から 5 分程 で多列砂州が形成されたが，通水開始 40 分後には 2 3 列砂州へと移行し河岸の浸食が始まった。他のケース と比較すると局所的な河岸の浸食は非常に少なく, 通 水後期は河道の拡幅がほぼ見られなかった。しかしな がら, 河岸近傍で相対的に洗掘の程度が大きい個所が 左右岸交互に出現しており, 蛇行流路に近い形状を示 


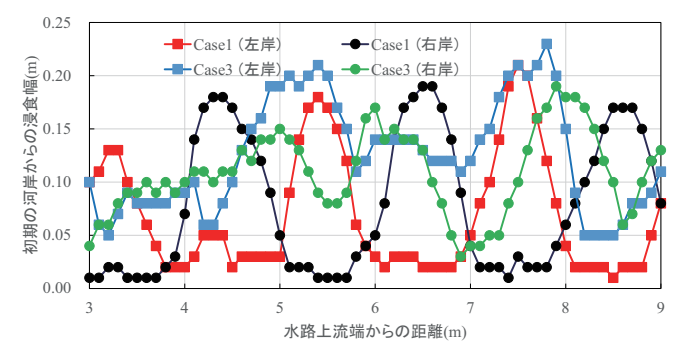

図-4 Case1 および Case3 における初期河岸からの浸食幅

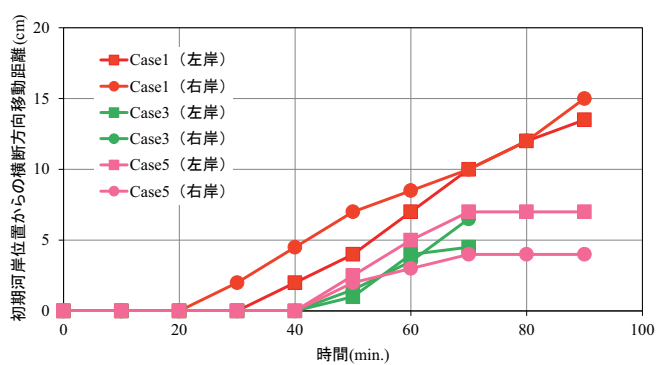

図-5 浸食河岸曲頂部位置の横断位置の時間変化

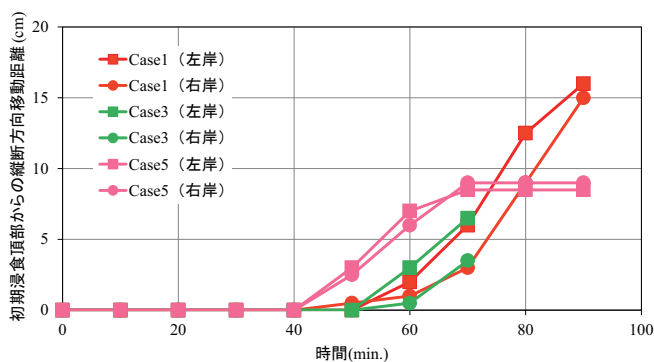

図-6 浸食河岸曲頂部位置の縦断方向の時間変化

す結果となった。

\section{(2) 河岸湾曲曲頂部の位置の時間変化}

水路上流端から $5 \mathrm{~m}$ の位置の水路上方に設置した力 メラで撮影した写真をもとに, 各ケースの浸食により 縦断方向に湾曲した河岸の曲頂部の位置の変化 (右岸 · 左岸) を測定した。なお，写真の範囲が限定されている ことから，1曲頂部の変化を対象としている．時系列で 整理したものが図-5 および図-6である．また，曲頂部 の平面的な位置の変化を, 図-7 に示す.なお, 測定は Case1, Case3, Case5 の 3 ケースとした. Case1 および Case3 における河岸浸食は, 最初に横断方向に進行し, その後縦断方向に位置を変化させている．特に，初期 流路幅が最も狭いCase1 では, 横断方向に浸食が始まっ てから縦断方向に移動するまでに 20 分以上の遅れが生 じている，一方，Case5 では縦横段方向にほぼ同時に浸 食が進行し, 縦断方向の浸食速度が横断方向の浸食速 度よりもやや大きくなっている. なお, 初期の横断方 向への浸食速度は，どのケースもおおむね $0.25 \mathrm{~cm} / \mathrm{min}$. 程度であった。

\section{（3）中規模河床波の移動速度}

河岸浸食が中規模河床波の移動に大きく影響を受け

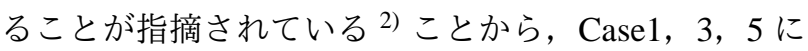
おける砂州の縦断方向の移動速度を水路上方のカメラ

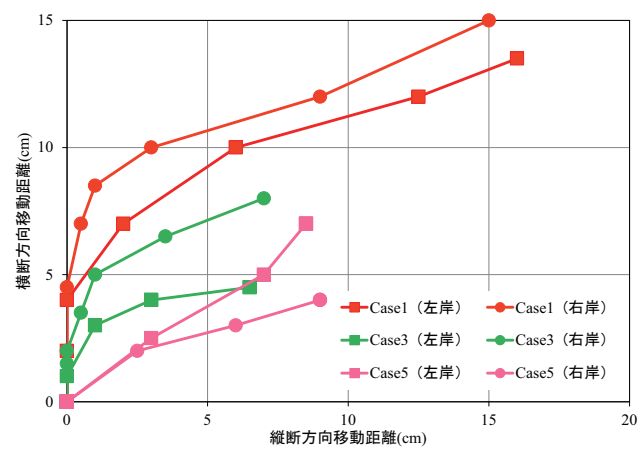

図-7 浸食河岸曲頂部の平面位置の変化

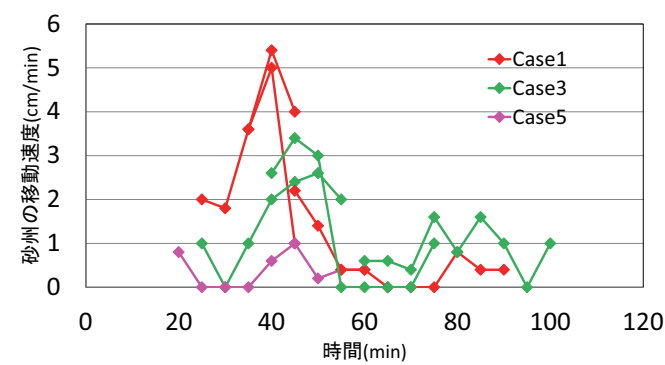

図-8 中規模河床波の流下方向移動速度

で撮影された写真をもとに測定を行った．時系列で整 理した結果を図-8に示す. 概観的には, 初期流路幅が 狭い Case1 が砂州の移動速度が最も速く, 流路幅が広 くなるに従って遅くなっていくことが見て取れる。ま た, Case1 およびCase3において, 初期の移動速度は大 きいものの, Case1 では通水開始後 45 分以降, Case3 では通水開始後 55 分以降に急激に移動速度が低下し, 通水停止までそのまま遅い速度で移動している。一方 Case5 は, Case1 や Case3 のように速い移動速度の時期 は無く, 通水開始から遅い速度のままで移動している.

\section{4. 中規模河床波の発達と河岸浸食の関係}

ここでは, 中規模河床波の発達と河岸浸食の関係に ついて，もっとも顕著であった Case1 を詳しく検討す ることとする.

Case1において，横断方向の河岸浸食が生じ始める 時刻は通水開始から 20〜30 分後であり, 通水開始から 50 分経過頃から縦断方向へ浸食位置が移動し始めてい る. 一方, 砂州の移動速度は, 通水開始後 40 分ごろま で加速しその後急激に速度を落とし 55 分以降縦断方向 への進行が極端に遅くなっている. 図-9および図-10 は，それぞれCase1における砂州の縦断方向下流への 移動速度が速い時期および移動速度が遅く縦横断方向 への河岸浸食が顕著になっている時期の連続写真を示 したものである. 河床波の発達に関して, 砂州波高は 直接測定していないため写真における砂州前縁線付近 の影の状況からの判断となるが, 通水開始後 35 分ごろ までの河床波の発達段階にあるときには砂州の縦断方 向下流への移動が徐々に速くなり, 砂州の波高が十分 発達してくる通水開始後 40 分ごろから砂州前縁線が横 

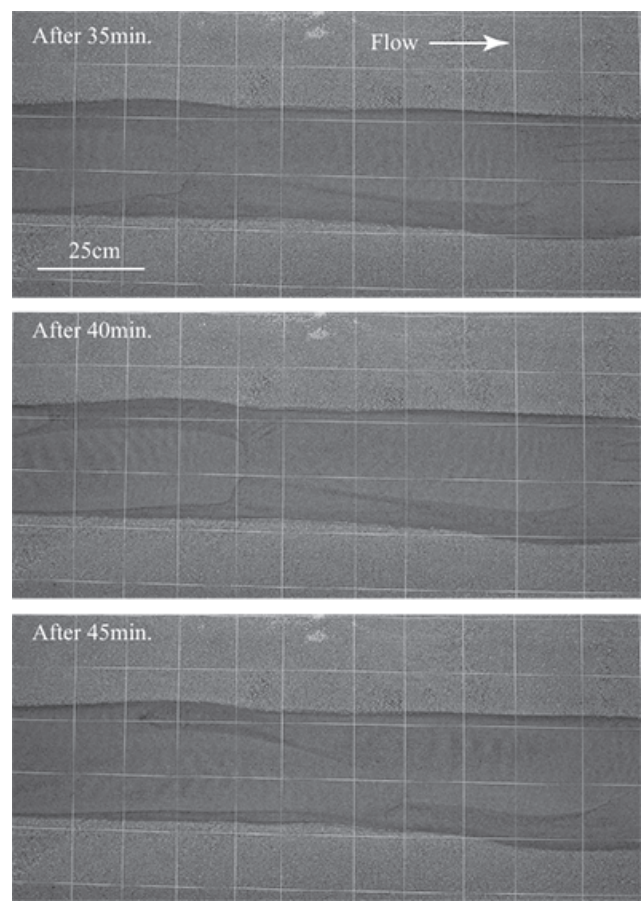

図-9 Case1 における交互砂州の移動が下流方向へ卓越してい る時期の連続写真

断方向に膨らみ縦断方向下流への移動が遅くなってい る. 通水開始後 60 分には, 砂州の先端の位置はほとん ど変化せず河岸の曲頂部が下流方向へ移動を開始して いる. なお，この時点においても，河岸の横断方向の 浸食速度は, 維持されている. すなわち, 中規模河床 波による局所的な河岸浸食の進展には, 中規模河床波 の波高の発達が必要であるとともに，河岸浸食により 中規模河床波の形状が大きく変化しており, 両者の関 係は非常に密接なものであると考えられる，なお，河 岸浸食に伴う局所的な流砂量の増加が中規模河床波に 与える影響や, 中規模河床波の横断方向への移動に伴 う波長への影響などは，写真の撮影範囲が限られてい たため不明であり, 今後の課題である.

なおこのような現象は，横断方向への河床波の発達 の程度は弱いものの, 多列砂州のモード現象が生じた Case3 や Case5 においても見られた.

\section{5. 河岸浸食に伴う河岸線の蛇行波長}

実験において形成された蛇行した河岸線の平面形状 の卓越波長を把握するために, 水路上下流端の影響を 受けていると推察される部分を除き, 流路の上流側の左 岸湾曲部頂点から下流側の左岸湾曲部頂点までの区間 を対象として, 波形解析を行なった. その結果を図-11 に示す. なお, 縦軸の振幅は $\widetilde{B}$ で基準化されたもので あり, 横軸の $\lambda$ は式(1)で表される值である. また, 得 られた卓越波数並びに卓越波長を表-2に示す.

$$
\lambda=2 \pi \underset{\widetilde{L}}{\widetilde{B}}
$$
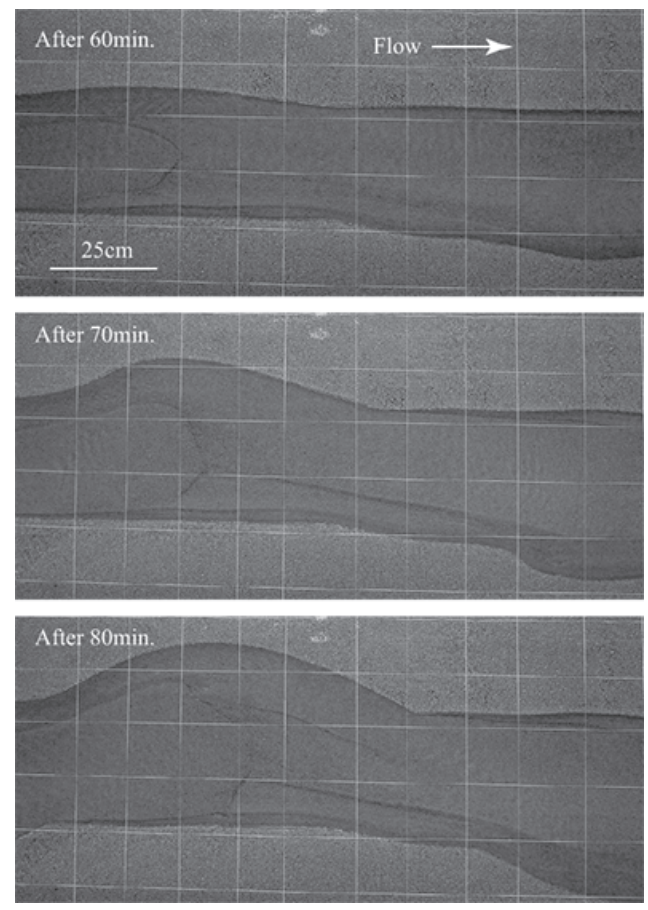

図-10 Case1 における交互砂州の移動がほぼ停止し河岸浸食 が縱横段方向へ顕著になっている時期の連続写真

表-2 卓越波数と卓越波長

\begin{tabular}{|c|c|c|c|c|c|}
\hline & Case1 & Case2 & Case3 & Case4 & Case5 \\
\hline$\lambda_{p}$ & 0.38 & 0.94 & 0.61 & 0.59 & 1.71 \\
\hline$\widetilde{L}_{p}(\mathrm{~m})$ & 2.07 & 1.00 & 2.33 & 3.20 & 1.38 \\
\hline
\end{tabular}

表-3 卓越波長の実験結果と解析結果の比較

\begin{tabular}{|c|c|c|c|c|}
\hline 単位 $; \mathrm{m}$ & 実験 & $\begin{array}{c}\text { 平面 } \\
\text { 不安定 } \\
\text { 結果 }\end{array}$ & $\begin{array}{c}\text { 中解析 } \\
\text { 河床波 } \\
\text { 安定解析 }\end{array}$ & 節腹連続 \\
\hline Case1 & 2.07 & 4.91 & 1.02 & 河道解析 \\
\hline Case3 & 2.33 & - & 0.93 & 0.97 \\
\hline
\end{tabular}

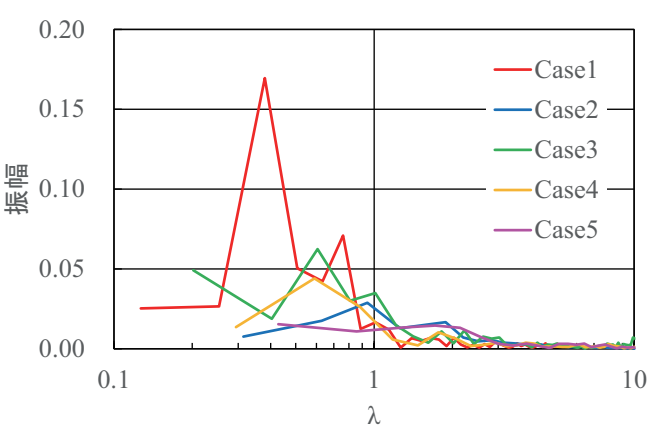

図-11 各ケースにおける縦断方向に蛇行した河岸線の波数解 析結果

ここで, $\widetilde{B}$ は初期流路幅の $1 / 2$ であり, $\widetilde{L}$ は波長である. 初期流路幅が $25 \mathrm{~cm}$ である Case 1 では, 振幅に関して 非常に明瞭なピークが表れ, 卓越波長が $2.07 \mathrm{~m}$ となる 結果を得た。また, 初期流路幅が $30 \mathrm{~cm}$ の Case 2 では, 不明瞭ながら卓越波長として $1.00 \mathrm{~m}$ を得た。初期流路 幅がそれぞれ $45 \mathrm{~cm}$ および $60 \mathrm{~cm}$ の Case 3 および Case 4 では, Case1 に比較すると明瞭さは落ちるものの, 卓越 
波長がそれぞれ $2.33 \mathrm{~m}$ および $3.20 \mathrm{~m}$ となっている. 一 方, 初期流路幅が $75 \mathrm{~cm}$ の Case5 では, 周期性は非常に 不明瞭であるが, 最大の振幅を持つ波長は, $1.38 \mathrm{~m}$ と なった。

\section{6. 実験結果と理論解析結果との比較}

蛇行流路及び節腹連続河道の成因について，比較的 明瞭な卓越波長をもつC Case 1 と Case 3 について考察を 行った。蛇行流路が形成された Case1については，実 験で得られた蛇行波長と固定河岸における中規模河床 波の線形安定解析の結果および平面不安定解析の結果 を, 明瞭な節腹連続河道が形成された Case3 について は，実験で得られた節腹の波長と固定河岸における中 規模河床波の線形安定解析の結果および浸食性河岸に おける節腹連続河道に対する線形安定解析の結果とを それぞれ比較することとした。平面不安定に伴う蛇行 波長は Blondeaux \& Seminara ${ }^{5)}$ の平面不安定理論にお ける摂動量の増幅率 $\operatorname{Re}\left[u_{1}\right]$ を, 固定河岸における中規 模河床波の波長は Colombini ら ${ }^{8)}$ の安定解析における 摂動量の増幅率 $\operatorname{Im}[\omega]$ を，また浸食性河岸における節 腹連続河道の波長は渡邊ら ${ }^{7)}$ の安定解析における増幅 率 $\operatorname{Im}[\omega]$ をそれぞれ利用することとした。すなわち， $\operatorname{Re}\left[u_{1}\right], \operatorname{Im}[\omega]$ および $\operatorname{Im}[\omega]$ の最も大きな值を示す波数 の波が生じることとなる. 結果を, それぞれ図-12およ び図-13に示す。また, 得られた卓越波数から算定した 卓越波長を表-3に示す.

Case1 の蛇行波長は，安定解析による交互砂州波長 の 2 倍程度であり, 平面不安定理論による波長の $1 / 2$ と なった. しかしながら, 図-11における Case1 の波数解 析の結果では, 図-12 横断波数 1 すなわち交互砂州の 卓越波数において, 第 2 のピークを持つ結果となって いる.この結果からは, 河岸浸食を伴う蛇行流路の形 成には交互砂州と平面不安定の両方の影響が関与して いるものと推察される.

一方, 節腹連続河道が形成された Case3 では, 河岸 浸食を考慮した節腹の波長と固定河岸における中規模 河床波に関する線形安定解析結果とはおおむね一致し ているが，実験結果の約 2 倍の波数となっている.

実験の観察から, 河岸浸食の進展に伴い砂州の成長 方向や移送速度が大きく変化することから，これらの 機構を取り込むことが必要であるとともに, 平面不安 定現象と中規模河床波の発達との非線形効果を取り込 んだ検討が必要であると考えられる。

\section{7. おわりに}

河岸浸食を伴う中規模河床波の形成に関する水理実 験を行い, 中規模河床波を要因とする河岸浸食の進展 には, 中規模河床波の十分な発達が必要であることが 判明した。また, 河岸浸食の進展とともに中規模河床 波の進行方向や移動速度が大きく変化する現象が確認

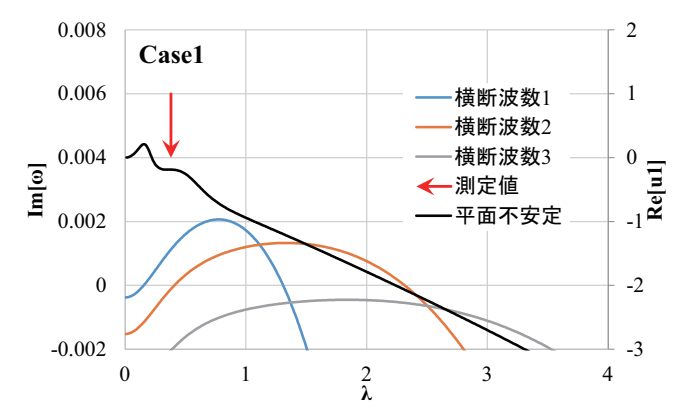

図-12 Case1 の蛇行波数と中規模河床波および平面不安定解 析結果との比較

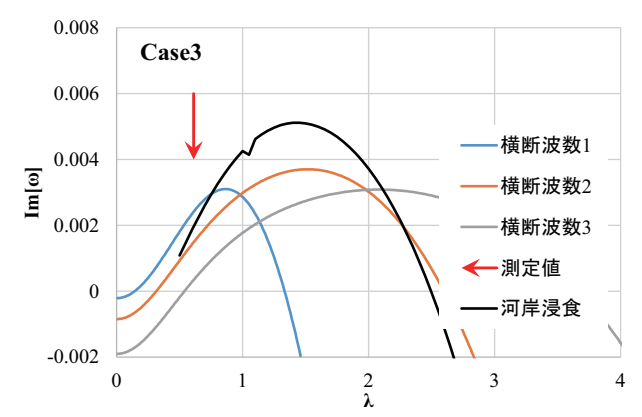

図-13 Case3 の蛇行波数と中規模河床波および節腹連続河道 解析結果との比較

されたことから, 蛇行河道や節腹連続河道の形状を議 論する場合には, 今後これらの現象を考慮した検討が 必要であると考えられる.

謝辞：本研究は, 国土交通省河川砂防技術研究開発公 募地域課題分野「河川景観ネットワークの連続性と時 空間変化（代表 : 中村太士）」の助成を受けて行われた. 記して謝意を表す。

\section{参考文献}

1) 木下良作 : 石狩川河道変遷調査, 科学技術庁資源局資料 36 号, 1961.

2) 藤田裕一郎, 村本嘉雄 : 流路形態の形成過程に関する研 究, 京大防災研究所年報第 23 号 B-2, pp475-492, 1982.

3) 土木学会水理委員会 : 洪水流の三次元流況と流路形態に関 する研究, 研究代表者; 芦田和男, 1982.

4) 島田龍市, 清水康行, 長谷川和義, 伊賀久晃: 砂州性蛇行 の形成に関する線形安定解析, 土木学会論文集 B1（水工 学) Vol.69, No.4, I 1147-I 1152, 2013.

5) Blondeaux,P. \& Seminara,G.: Aunifie bar-bend theory of river meanders. J. Fluid Mech. 157, pp.449-470, 1985.

6) Uddin M. J., Izumi N. \& Hasegawa K.: Bar instability accompanied by bank erosion, Advances in River Sediment Research, pp.467-472, 2013.

7) 渡邊康玄, 長谷川和義, 吉川泰弘, 早川博 : 節腹連続河道 の形成に関する線形安定解析, 土木学会論文集 B1（水工 学) Vol.70, No.4, I -I , 2014.

8) Colombini, M., G. Seminara \& M. Tubino: Finite amplitude alternate bars. Journal of Fluid Mechanics. Vol. 181, pp213232, 1987. 